\title{
After work is done: psychological perspectives on recovery from work
}

Citation for published version (APA):

Zijlstra, F. R. H., \& Sonnentag, S. (2006). After work is done: psychological perspectives on recovery from work. European Journal of Work and Organizational Psychology, 15(2), 129-138.

https://doi.org/10.1080/13594320500513855

Document status and date:

Published: 01/01/2006

DOI:

10.1080/13594320500513855

Document Version:

Publisher's PDF, also known as Version of record

Document license:

Taverne

Please check the document version of this publication:

- A submitted manuscript is the version of the article upon submission and before peer-review. There can be important differences between the submitted version and the official published version of record.

People interested in the research are advised to contact the author for the final version of the publication, or visit the DOI to the publisher's website.

- The final author version and the galley proof are versions of the publication after peer review.

- The final published version features the final layout of the paper including the volume, issue and page numbers.

Link to publication

\footnotetext{
General rights rights.

- You may freely distribute the URL identifying the publication in the public portal. please follow below link for the End User Agreement:

www.umlib.nl/taverne-license

Take down policy

If you believe that this document breaches copyright please contact us at:

repository@maastrichtuniversity.nl

providing details and we will investigate your claim.
}

Copyright and moral rights for the publications made accessible in the public portal are retained by the authors and/or other copyright owners and it is a condition of accessing publications that users recognise and abide by the legal requirements associated with these

- Users may download and print one copy of any publication from the public portal for the purpose of private study or research.

- You may not further distribute the material or use it for any profit-making activity or commercial gain

If the publication is distributed under the terms of Article $25 \mathrm{fa}$ of the Dutch Copyright Act, indicated by the "Taverne" license above, 


\section{After work is done: Psychological perspectives on recovery from work}

\section{Professor Fred R. H. Zijlstra \& Sabine Sonnentag}

To cite this article: Professor Fred R. H. Zijlstra \& Sabine Sonnentag (2006) After work is done: Psychological perspectives on recovery from work, European Journal of Work and Organizational Psychology, 15:2, 129-138, DOI: 10.1080/13594320500513855

To link to this article: https://doi.org/10.1080/13594320500513855

$$
\text { Published online: } 24 \text { Feb } 2007 .
$$

Submit your article to this journal $₫$

Џll Article views: 3735

Q View related articles $\asymp$

4 Citing articles: 35 View citing articles 


\title{
After work is done: Psychological perspectives on recovery from work
}

\author{
Fred R. H. Zijlstra \\ Department of Psychology, School of Human Sciences, University of Surrey, \\ Guildford, UK \\ Sabine Sonnentag \\ Work and Organizational Psychology, Department of Psychology, University \\ of Konstanz, Konstanz, Germany
}

\section{INTRODUCTION}

Research on the relation between work and health has primarily focused on the effects of psychosocial characteristics of the job (i.e., autonomy, psychological demands) on psychological well-being and other healthrelated outcomes. However, in the last decade the awareness has risen that an integral part of a healthy life is an adequate balance between work and private life (work-life balance, work-family balance; cf. Jones, Burke, \& Westman, 2005). Part of a healthy life style is recovering from the daily strains. The topic of recovery from work has not received much scientific attention, and consequently the process of recovery is not yet well understood (for reviews, cf. Eden, 2001a, 2001b). With this special issue we want to contribute to the understanding of the process of recovery, and we hope that this issue will help to put this topic on the research agenda. This special issue presents a selection of articles that look into different aspects related to recovery, such as aspects that are work-related and aspects that are related to the time after work. In this introduction we will outline some background information that is needed to position the concept of

Correspondence should be addressed to Professor Fred R. H. Zijlstra, Faculty of Psychology, Maastricht University, P.O. Box 616, NL 6200 MD Maastricht, The Netherlands. E-mail: fred.zijlstra@psychology.unimaas.nl

(C) 2006 Psychology Press Ltd 
recovery, and to highlight the psychological perspectives on recovery. First, we will discuss the relation of recovery with fatigue, and then we will present the "cycle of work and rest". Subsequently, we will address the relationship between work characteristics and recovery and will describe the relevance of leisure and sleep.

\section{FATIGUE AND RECOVERY}

Intuitively it is evident that after a period of work people need some rest to recover. During the working day people are confronted with all kind of demands, ranging from physical and cognitive to emotional demands. Dealing with these demands requires physical work, attention, and concentration, in short expending physical and/or mental energy. Energy expenditure is what makes people feel fatigued by the end of the working day because their resources are depleted, both in energetic and emotional respect (cf. Meijman, Mulder, \& van Dormolen, 1992). These feelings of fatigue require people to take a rest in order to recuperate from their effort investments and to allow their resources to be replenished. This process of replenishing resources is usually indicated as "recovery". Recovery is important because it allows people to prepare and be ready for new challenges (i.e., another day at work), and it will prevent accumulation of fatigue that ultimately can lead to serious health consequences.

From a conceptual point of view, recovery should be seen as a process that allows us to replenish our resources. In essence this is what we do when we take a rest or go to sleep. The implication of taking a rest is that one is (temporary) relieved of the demands, and this relief will allow to replenish the resources that have been used. The anticipated effect of the recovery process is reduction of fatigue. In physiological sense this implies that the organism is allowed to "unwind", which actually means that the arousal level (as indicated by adrenaline excretion rate and heart rate) is allowed to return to a "baseline level" again (Craig \& Cooper, 1992). The psychological effects to be anticipated are that people feel capable and ready to continue with the current demands or to meet new demands. A common expression referring to this effect is "charging the batteries". This means that work and rest need to alternate and should constitute a "cycle of work and rest".

However, for various reasons it is not always feasible to take a rest, thus other options need to be explored. In many cases changing activities has a similar effect as taking a rest, because a change in activities is often accompanied by a change in demands (e.g., alternating physical activities with mental activities). As a consequence different resources are used (e.g., muscles vs. "brain power"). In fact this is what people actually do: after work they engage in various types of activities, varying from household activities and childcare to sports and leisure. 


\section{CYCLE OF WORK AND REST}

The "cycle of work and rest" is primarily determined by the working times. While at work people are not supposed to rest; resting is what they should do in their "own time". The lunch and coffee/tea breaks are illustrations of this: Employers usually do not pay salary over lunch breaks. Working times are therefore important; they specify when people have to be at work, and when they are "free to go". The time "after work" traditionally is the time in which people should be able to recover from the daily strains at work. This pattern in principle repeats itself every day, and therefore is referred as the "cycle of work and rest". However, the time after work is not only for recovery. Many people have commitments and duties after work and are not entirely free to spend their time. Some of these commitments and duties will place additional demands upon people and some of these demands will be similar to work demands, while other activities have entirely different demands. The question is how these demands interact with the demands of work: Are they to be added on top of the work demands or do they compensate for the work demands? Already in the late 1970s, Piotrkowsky (1978) reported that some workers were just too drained by physical tiredness or by working in boring jobs that they developed apathy for family life and other activities. Although numerous things have changed over the last decades, such as the fact that work nowadays is primarily mentally demanding rather than physically demanding (Zijlstra, Schalk, \& Roe, 1996), yet the number of people complaining about work pressure and fatigue is still high (Paoli \& Merllié, 2001). Paoli and Merllié reported on a survey among the working population in Europe. Their results indicate that more than half of the working population in Europe complained about having to work under pressure (i.e., either working at high speed, or having to meet tight deadlines). Occupationally induced fatigue, i.e., the short-term effect of a working day, is a common complaint, affecting about $25-33 \%$ of the working population in the Netherlands (Bultmann et al., 2002). The fatigue people experience may have an effect on what kind of activities they are willing to undertake after work. People may decide that they are too tired for certain activities or initiatives and thus stay at home and resort to a passive type of leisure (i.e., watching television).

Working times are not only important in terms of work and rest, but they are one of the first and most important aspects of work organisation: It synchronizes people's presence and therefore facilitates any form of organizing and cooperation. In particular since the industrial revolution, when mass-production in factory plants started, the regulation of working times has become an issue. One of the consequences of regulated working times is that people have less influence over the decisions of when to work and when to take a break - nowadays the majority of employees have no flexibility, or decision authority, with respect to their working times. In 
addition, people sometimes have to work extra hours, and this may affect the cycle of work and rest.

Recent technological developments have had an impact on working times. Internet and mobile communication facilities allow people to work from wherever they want, and whenever they choose to work. This development has introduced the phenomenon of "tele-homework" and "distance work", which in fact has decreased the importance of working times (Roe et al., 1994). Working late in the evening necessarily reduces the opportunity for recovery. Rau and Triemer (2004) found that people who regularly worked overtime had more sleep problems than those who worked regular hours. However, people in that study worked in their official work place and not at home. Studies on (tele-)homework suggest that the boundaries between work and private life tend to diminish (Ahrentzen, 1990), and that as a result people find themselves working late night. Some people complain that it feels as if they are never finished. So, from a recovery point of view this seems to have undesirable consequences; it evidently affects the daily work-rest cycle. Apparently the boundaries between work and home have an important psychological function: They help people to create a psychological distance between work and themselves, which is necessary to unwind. When these boundaries between work and home become less clear people seem not able to distance themselves from the demands being imposed upon them, and therefore will have difficulties disengaging themselves from work (see Cropley, Dijk, \& Stanley, 2006 this issue; Sonnentag \& Kruel, 2006 this issue).

Yet there are many interesting questions related to the cycle of work and rest, and thus to the topic of recovery, such as "what is the optimum period for work and for rest?", "what factors facilitate recovery?", "how does recovery impact on subsequent work behaviour'? "How should jobs be designed so that recovery is facilitated?", "What is the role of sleep with respect to recovery from work'? And more questions could be formulated.

\section{WORK CHARACTERISTICS AND RECOVERY}

As indicated above working times and thus the length of the working day determine people's opportunity to recover. However, the characteristics of the job itself also appear to have an effect on recovery. The extent to which people can "switch off" from work in the evening seems to be important. Studies have indicated that the intensity of the working day plays a role in this respect. For example, Meijman et al. (1992) have demonstrated that people working in intensive working conditions have more difficulties in unwinding during the evening compared to people who do similar work but face less intensive conditions. Furthermore, the level of autonomy at work is important because it allows people to regulate their own work speed (Jackson, Wall, Martin, \& Davids, 1993), and therefore also their own level of effort investment (cf. 
Zijlstra, 1993; Zijlstra, Roe, Leonova, \& Krediet, 1999). In general one could say that when work is very demanding, for example when it is characterized by high levels of responsibility or high work pressure, it can cause a feeling of strain, which in itself leads to a greater need for recovery (Sluiter, van-derBeek, \& Frings-Dresen, 1999), but may also make it more difficult for individuals to unwind after work (Sonnentag \& Bayer, 2005). This means that the nature of the working day has an effect on the type of activities people engage in after work. Optimal recovery from work is dependent on the opportunity and time for recovery and the type and quality of activities people pursue (Sonnentag, 2001; Sonnentag \& Zijlstra, 2006).

\section{LEISURE AND RECOVERY}

Most people in our society consider work to be the dominant activity and leisure as being trivial. This view on work and leisure is a consequence of what is called the Puritan (or Protestant) work ethic, in which work is glorified and leisure is devalued. In such situations leisure becomes a derivate of work, solely used for recuperation and distraction (Hunnicut, 1988). However, the essence of leisure is "perceived freedom and intrinsic motivation" to engage in activities (Iso-Ahola, 1980). This view is in strong contrast to most work situations, where people's activities are usually externally prescribed and regulated, and perceived as an obligatory duty. At work people have a contractual obligation to be present and perform particular activities. Also, other activities that people engage in during "after work time" are not always intrinsically motivated, but people do engage in these activities out of their free will; there is no contractual obligation.

Some people see the merits of leisure in its own right (Iso-Ahola, 1997). Leisure activities can, like work, have beneficial effects on mental health and personality development (see also Rau, 2006 this issue). In societies that do not value leisure, people are not able to reconcile work and family, have little time for cultivating hobbies, and find it difficult to engage in civic activities that would nourish a democratic society. Also from a psychological perspective it would be better if people engaged in activities in which they sought challenges and tried to match them with their skills. Evidently this also applies to work: Optimal experiences correlate positively with mental health (Csikszentmihalyi, 1990).

However, in our society leisure is used as an "escape" from work. "Escapism" in this respect means that people do not seek meaningful leisure activities for their own growth and development, but, instead, resort to passive activities to escape from everyday strains and problems. Such behaviour is frequently associated with a passive lifestyle and boredom, which in turn might feed into apathy and depression. From this perspective is it rather worrisome that watching television seems to be the dominant activity for many people in 
their "after work time". Schor (1991) referred to this as part of the "workspend-work-spend" mentality that seems to be prevalent in our society.

\section{SLEEP AND RECOVERY}

Sleep plays a very important role in the process of recovery. It is assumed that sleep must be continuous in order to be restorative (Walsh \& Lindeblom, 2000). Sleep loss and sleep disturbance can lead to mood changes, fatigue, and performance decrement and in extreme cases even to immune function impairment (Harrison \& Horne, 1999). Even moderate sleep loss is associated with deficits in alertness and performance (Åkerstedt, Knutsson et al., 2002; Dinges et al., 1997). Lack of sleep or poor quality of sleep is also associated with absenteeism, reduced productivity, and an increased risk of fatigue-related accidents (A kerstedt, Fredlund et al., 2002; Stoller, 1994). Lack of sleep or disrupted sleep can result in not feeling refreshed the in the morning. When people are not refreshed this suggests that they haven't completely recovered, and are not in an optimal condition to meet new demands and challenges. Work will then cost extra effort (Zijlstra, 1993). The implication is that lack of recovery can lead to accumulation of fatigue and strain and ultimately can cause health problems.

Most studies in the domain of work and health have neglected the area of sleep. This is surprising considering the association between high work demands and sleep disturbance (Åkerstedt, Knutsson et al., 2002; Cropley, Steptoe, \& Joekes, 1999). However, the mechanisms by which occupational stress is associated with sleep disturbance are not yet fully understood. One possibility may be that people in stressful jobs are very active during the evening and therefore are too physiologically aroused at bedtime what causes difficulties in falling asleep. They need to "unwind" first. Another possibility is that people may have difficulties in "switching off" from work-related issues and thoughts at bedtime, and thus still ruminate about the problems at work and thus have difficulties in falling asleep. Harvey (2000) showed that presleep cognition affects sleep quality, and manipulations of cognitive arousal before sleep leads to longer sleep latencies (Gross \& Borkovec, 1982).

In particular when people have problems to deal with at work or when they experience conflicts at work, people may have ruminative thoughts, which make it difficult to switch off from work. A recent survey on sleep behaviour found that about $17 \%$ of a representative sample of the working population in the UK reported that they have sleeping problems caused by worrying about their work (Groeger, Zijlstra, \& Dijk, 2004). Studies have shown that a failure to unwind after work leads to sleep complaints, and consequently makes people feel not-refreshed the next morning (Meijman et al., 1992; Sluiter et al., 1999). Thus, sleep problems are associated with fatigue, and can have an impact on recovery. 


\section{THIS ISSUE}

Health and well-being are related to both people's work and leisure activities. Mental health problems (e.g., psychological complaints such as burnout, depressive feelings, and stress-related complaints) are currently the fastest-growing category mentioned among long term absentees from work, indicating that this is a serious problem. As individuals' energetic resources are not infinite, they have to recover form time to time.

Although there is increasing evidence that the process of recovery is important for a healthy and balanced life (cf. Gump \& Matthews, 2000), this process has not yet received the scientific attention it deserves. A few studies have looked into the effects of holidays and vacations (Fritz \& Sonnentag, in press; Strauss-Blasche, Muhry, Lehofer, Moser, \& Markl, 2004; Westman \& Eden, 1997; Westman \& Etzion, 2001). These studies have indicated that vacations have a beneficial effect on well-being; however, these effects are usually short lived. A more structural solution is desirable, and this requires a better understanding of the process of recovery. It is intuitively clear that sleep is important for recovery, although the exact mechanisms and processes in this respect are not entirely clear yet. There are indications that day time activities also have an effect on recovery. The question is whether daytime activities affect recovery because they affect people's sleep or whether they have an effect in their own right. But there are more questions that need to be answered, such as "what are the determinants of optimal recovery?" and "how do activities during the day affect the recovery process?"

This issue presents five articles that address various aspects related to recovery. One important topic refers to the extent to which job characteristics are associated with recovery. The study by Taris and colleagues focuses on the aspects of working times and deals with the question whether contract working time and overtime may affect the opportunities for recovery, and thus may reduce recovery. Analyses showed that in a sample of managers contract working hours were negatively related to exhaustion. Overtime was positively related to work enjoyment, but also to time-based work home interference.

Cropley and colleagues address the issue of the association between job strain and sleep quality. The article provides evidence that people working in high strain jobs need longer to unwind after work and ruminate more about work-related issues. The study also demonstrates that there is a positive association between high strain jobs and sleeping problems.

The article by Rau reports findings from a study that included physiological data. The study provided evidence that job incumbents whose jobs are well-designed and who have opportunities to develop themselves are better off not only in terms of mental health, but also in terms of recovery. Analyses showed that high learning opportunities - as assessed by 
behavioural data - were positively related to a pronounced decline of heart rate and blood pressure during the night. Such a decline is a strong indicator for successful cardiovascular recovery.

The article by Sonnentag and Kruel presents a study that examined the relation between job stressors and people's ability to switch off after work. Specifically, the study showed that teachers experiencing a high workload had more difficulties "switching off" from work during the evening. Interestingly, this relationship is not only based on self-report data but is also reflected in observations provided by family members. Together the articles by Cropley and colleagues, Rau, as well as Sonnentag and Kruel suggest that work characteristics encountered during the day extends its effect during the after-work period and affects the recovery process.

The article by Rook and Zijlstra presents a study on the weekly pattern of fatigue and sleep quality, and examines the contribution of various activities towards recovery. Sport activities turned out to be negatively associated with fatigue. Interesting to note is that people apparently seem to anticipate the strain of the working week, given the fact that the lowest sleep quality is found on Monday morning. This finding suggests that recovery is a highly complex process in which also anticipatory and expectation processes play an important role (Eden, 2001b).

Thus, as a whole the studies present a complex picture of work and recovery. Important factors that potentially impact on recovery and opportunities for recovery include workload as well as aspects of job control and learning requirements. Recovery itself is reflected in psychological detachment from work, low fatigue, as well as sleep and decrease in physiological parameters during the night.

Recovery from work is an important topic. Articles in this issue illustrate that when work and organizational psychologists want to learn more about people's well-being they also need to look at "after-work time". This special issue certainly does not pretend to answer all the questions that have been formulated, but we do hope that it stimulates further investigations on this important topic.

\section{REFERENCES}

Ahrentzen, S. B. (1990). Managing conflict by managing boundaries: How professional homeworkers cope with multiple roles at home. Environment and Behavior, 22, 723-752.

Åkerstedt, T., Fredlund, P., Gillberg, M., \& Jansson, B. (2002). A prospective study of fatal occupational accidents - relationship to sleeping difficulties and occupational factors. Journal of Sleep Research, 11, 69-71.

Åkerstedt, T., Knutsson, A., Westerholm, P., Theorell, T., Alfredsson, L., \& Kecklund, G. (2002). Sleep disturbances, work stress and work hours: A cross-sectional study. Journal of Psychosomatic Research, 53, 741-748. 
Bultmann, U., Kant, I., Kasl, S. V., Schroer, K. A. P., Swaen, G. M. H., \& van den Brandt, P. A. (2002). Lifestyle factors as risk factors for fatigue and psychological distress in the working population: Prospective results from the Maastricht Cohort Study. Journal of Occupational and Environmental Medicine, 44, 116-124.

Craig, A., \& Cooper, R. E. (1992). Symptoms of acute and chronic fatigue. In A. P. Smith \& D. M. Jones (Eds.), Handbook of human performance (Vol. 3, pp. 289-339). London: Academic Press.

Cropley, M., Dijk, D.-J., \& Stanley, N. (2006). Job strain, work rumination, and sleep in school teachers. European Journal of Work and Organizational Psychology, 15(2), 181-196.

Cropley, M., Steptoe, A., \& Joekes, K. (1999). Job strain and psychiatric morbidity. Psychological Medicine, 29, 1411-1416.

Csikszentmihalyi, M. (1990). Flow. New York: Harper \& Row.

Dinges, D. F., Pack, F., Williams, K., Gillen, K. A., Powell, J. W., Ott, G. E., et al. (1997). Cumulative sleepiness, mood disturbance, and psychomotor vigilance performance decrements during a week of sleep restricted to 4-5 hours per night. Sleep, 20, 267-277.

Eden, D. (2001a). Job stress and respite relief: Overcoming high-tech tethers. In P. L. Perrewé \& D. C. Ganster (Eds.), Research in occupational stress and well-being: Exploring theoretical mechanisms and perspectives (pp. 143-194). Amsterdam: JAI Press.

Eden, D. (2001b). Vacations and other respites: Studying stress on and off the job. In C. Cooper \& I. Robertson (Eds.), Well-being in organisations: A reader for students and practitioners (pp. 121 -146). Chichester, UK: Wiley.

Fritz, C., \& Sonnentag, S. (in press). Recovery, well-being, and performance-related outcomes: The role of workload and vacation experiences. Journal of Applied Psychology.

Groeger, J. A., Zijlstra, F. R. H., \& Dijk, D.-J. (2004). Sleep quantity, sleep difficulties and their perceived consequences in a representative sample of some two thousand British adults. Journal of Sleep Research, 13, 359-371.

Gross, R. T., \& Borkovec, T. D. (1982). The effects of a cognitive intrusion manipulation on the sleep-onset latency of good sleepers. Behaviour Therapy, 13, 112-116.

Gump, B., \& Matthews, K. (2000). Are vacations food for your health? A 9-year mortality experience after the multiple risk factor intervention trial. Psychosomatic Medicine, 62, $608-612$.

Harrison, Y., \& Horne, J. A. (1999). One night of sleep loss impairs innovative thinking and flexible decision making. Organizational Behavior and Human Decision Processes, 78, $128-145$.

Harvey, A. G. (2000). Pre-sleep cognitive activity: A comparison of sleep-onset insomniacs and good sleepers. British Journal of Clinical Psychology, 39, 275-286.

Hunnicut, B. (1988). Work without end: Abandoning of shorter hours for the right to work. Philadelphia: Temple University Press.

Iso-Ahola, S. (1980). The social psychology of leisure and recreation. Dubuque, IA: W.C. Brown.

Iso-Ahola, S. (1997). A psychological analysis of leisure and health. In J. T. Haworth (Ed.), Work, leisure and well-being (pp. 131-144). London: Routledge.

Jackson, P. R., Wall, T. D., Martin, R., \& Davids, K. (1993). New measures of job control, cognitive demand, and production responsibility. Journal of Applied Psychology, 78, 753-762.

Jones, F., Burke, R., \& Westman, M. (Eds.). (2005). Work-life balance: A psychological perspective. Hove, UK: Psychology Press.

Meijman, T. F., Mulder, G., \& van Dormolen, M. (1992). Workload of driving examiners: A psychophysiological field study. In H. Kragt (Ed.), Enhancing industrial performances (pp. 245-260). London: Taylor \& Francis.

Paoli, P., \& Merllié, D. (2001). Third European survey on working conditions 2000. Dublin: European Foundation for the Improvement of Working and Living Conditions. Retrieved from http://www.eurofound.eu.int/publications/files/EF9721EN.pdf 
Piotrkowski, C. S. (1978). Work and the family system. New York: Free Press.

Rau, R. (2006). Learning opportunities at work as predictor for recovery and health. European Journal of Work and Organizational Psychology, 15(2), 158-180.

Rau, R., \& Triemer, A. (2004). Overtime in relation to blood pressure and mood during work, leisure, and night time. Social Indicators Research, 67, 51-73.

Roe, R. A., van den Berg, P. T., Zijlstra, F. R. H., Schalk, M. J. D., Taillieu, T. C. B., \& van der Wielen, J. M. M. (1994). New concepts for a new age: Information service organizations and mental information work. The European Work and Organizational Psychologist, 3, 177-192.

Rook, J. W., \& Zijlstra, F. R. H. (2006). The contribution of various types of activities to recovery. European Journal of Work and Organizational Psychology, 15(2), 218-240.

Schor, J. (1991). The overworked American: The unexpected decline of leisure. New York: Basic Books.

Sluiter, J. K., van-der-Beek, A. J., \& Frings-Dresen, M. H. V. (1999). The influences of work characteristics on the need for recovery and experienced health: A study on coach drivers. Ergonomics, 42, 573-583.

Sonnentag, S. (2001). Work, recovery activities, and individual well-being: A diary study. Journal of Occupational Health Psychology, 6, 196-210.

Sonnentag, S., \& Bayer, U.-V. (2005). Switching off mentally: Predictors and consequences of psychological detachment from work during off-job time. Journal of Occupational Health Psychology, 10, $393-414$.

Sonnentag, S., \& Kruel, U. (2006). Psychological detachment from work during off-job time: The role of job stressors, job involvement, and recovery-related self-efficacy. European Journal of Work and Organizational Psychology, 15(2), 197-217.

Sonnentag, S., \& Zijlstra, F. R. H. (2006). Job characteristics and off-job time activities as predictors for need for recovery, well-being, and fatigue. Journal of Applied Psychology, 91, $123-142$.

Stoller, M. K. (1994). Economic effects of insomnia. Clinical Therapy, 16, 873-897.

Strauss-Blasche, G., Muhry, F., Lehofer, M., Moser, M., \& Markl, W. (2004). Time course of well-being after a three-week resort-based respite from occupational and domestic demands: Carry-over, contrast and situation effects. Journal of Leisure Research, 36, 293-309.

Taris, T. W., Beckers, D., Verhoeven, L. C., Geurts, S. A. E., Kompier, M. A. J., \& van der Linden, D. (2006). Recovery opportunities, work-home interference, and wellbeing among managers. European Journal of Work and Organizational Psychology, 15(2), $139-157$.

Walsh, J. K., \& Lindblom, S. S. (2000). Psychophysiology of sleep deprivation and disruption. In M. R. Pressman \& W. C. Orr (Eds.), Understanding sleep: The evaluation and treatment of sleep disorders (pp. 73-110). Washington, DC: APA.

Westman, M., \& Eden, D. (1997). Effects of a respite from work on burnout: Vacation relief and fade-out. Journal of Applied Psychology, 82, 516-527.

Westman, M., \& Etzion, D. (2001). The impact of vacation and job stress on burnout and absenteeism. Psychology and Health, 16, 595-606.

Zijlstra, F. R. H. (1993). Efficiency in work behaviour: A design approach for modern tools (PhD thesis, Delft University of Technology). Delft, The Netherlands: Delft University Press.

Zijlstra, F. R. H., Roe, R., Leonova, A. B., \& Krediet, I. (1999). Temporal factors in mental work: Effects of interrupted activities. Journal of Occupational and Organizational Psychology, 72, 163-186.

Zijlstra, F. R. H., Schalk, M. J. D., \& Roe, R. A. (1996). Veranderingen in de Arbeid. Consequenties voor Werkenden [Changes in work: Consequences for working people]. Tijdschrift voor Arbeidsvraagstukken, 12, 251-263. 